\title{
Impact of Settlement Growth on Yenagoa's Urban Environment
}

\author{
E. E. Imaitor-Uku, O. B. Owei, L. Hart, and A. Ayotamuno
}

ABSTRACT

This research is a study on the assessment of settlement growth and its impact on the urban environment in Yenagoa Metropolis. Landsat imageries of 1988, 1996, 2004, 2012 and 2020 were acquired from the United Sates Geographical Survey. Supervised image classifications using level 1 classification scheme was adopted to extract LandUse/LandCover. The five Epochs of images were used to extract the built-up areas, water bodies and vegetation areas. The area (ha) of land use for each epoch was determined using clipping images. The spatio-temporal changes were determined as a percentage of LULC per epoch and which was done following standard methods. Mapping technique was used to compare satellite imageries. Findings showed that built up areas was 1,279.81 in 1988, 2,497.87 in 1996, 4,554.73 in 2009, 7,804.30 in 2012 and 10,447.50 in 2020. While the percentage change of built-up are in 1988 was $6.12 \%, 1996$ was $11.94 \%, 2004$ was $21.78 \%, 2012$ was $34.31 \%$ and 2020 was $30.09 \%$, respectively. It is therefore recommended here that government should empower urban planning and development agencies, legally and financially to carry out their responsibility to implement existing master plan of the city. Engage in citizen education on how to contribute in managing the environment and sustainable land use management framework in the study area for proper management of the urban environment to enhance sustained settlement growth in the city.

Keywords: Impact, Settlement Growth, Yenagoa, Urban Environment

Published Online: February 9, 2021

ISSN: $2684-446 \mathrm{X}$

DOI :10.24018/ejgeo.2021.2.1.107

\section{E. E. Imaitor-Uku*}

Department of Geography, Jasper Isaac Boro College of Education, Sagbama, Bayelsa state, Nigeria.

(e-mail: naindemosu@gmail.com)

O. B. Owei

Department of Urban and Regional Planning, Rivers State University, Port Harcourt, Rivers State, Nigeria. (e-mail: owei.ob ${ }^{\circledR}$ ust.edu.ng)

L. Hart

Department of Urban and Regional Planning, Rivers State University, Port Harcourt, Rivers State, Nigeria.

(e-mail: Lawrence.hart ust.edu.n)

A. Ayotamuno

Department of Urban and Regional Planning, Rivers State University, Port Harcourt, Rivers State, Nigeria.

(e-mail: augustaayotamuno@yahoo.com)

*Corresponding Author

\section{INTRODUCTION}

The world has witnessed rapid growth in urban population, and this is more prominent in developing countries. Urbanization statistics showed a global population increase from 737 million in 1950 to 3.5 billion in 2016 [10]. It was estimated by the United Nations that $54.5 \%$ of the world's population lived in urban areas. The UN projected that from 2010, almost all growth in the world's population will be in urban centres in low and medium income nations [14]. It is also estimated that about $60 \%$ of the population of the third world countries will live in cities [10]. The growth of a city is a welcome development, but the management of these growths is very important for sustainable urban environment to be achieved. It has been reported [3] that Britain, by any standard, is one of the most urbanized countries and that the greatest over all change in settlement was the massive urbanization that accompanied Britain's early industrial development. Though, it had a lot of urban and sub-urban concentrations and the growth has been effectively managed. However, attendant problem of air, water and noise pollution, existed [3]. Urbanization in developing countries is a complex process, accompanied by informal settlements growth, rural-urban migration, inadequate infrastructure, and urban services [1].

A lot of factors could have negative effects on the earth's environment to a very large extent. Some of these factors are worth emphasizing. Settlement growth is one of the factors [10]. In another case, [15] examined the urban growth of Kampala in Uganda. The urban growth of Kampala was mapped using Landsat imageries of 1989, 1995, 2003 and 2010 and a spatially-explicit logistic regression model was developed for Kampala. The presence of roads, the accessibility of the city centre and the distance to existing built-up area were used as predictors in the model. The findings revealed that the alternative policy opinions result in contrasting future urban sprawl patterns with significant impact in the local quantity of life. Furthermore, [9] in his study of urban growth in the city of Amman in Jordan showed that the city has been transformed in respect to urban growth through establishment of institutions, laws, regulations, plans and the actions of politicians and other stakeholders. In yet another instant, study of urban growth in the city of Nairobi [13] it was revealed that establishment of railway headquarters brought continuous urban growth and increased the formation of informal settlements such as slums and squatters, transportation problems and demand for mid-low income housing in the city.

In Nigeria, a couple of investigative studies exist. For instance, [11] analyzed the settlement expansion and urban growth modelling using geo-information for assessing potential impacts of urbanization on climate in Abuja Nigeria. He used geo-information and ancillary data sets, land cover map derived from Landsat images for 1986, 2001 
and 2004, and quantitative spatio-temporal analysis was conducted to defect land use, land cover changes with specific focus on the settlement development pattern in Abuja FCT. Their findings showed that urban areas increased by more than $11 \%$ between 1986 and 2001 and later increased to $17 \%$ between 2001 and 2004, implying that settlement expansion is taking allotted spaces for green areas and agricultural lands. In addition, [4] studied landuse/land cover changes and causes of deforestation in the Wilberforce Island Bayelsa state, Nigeria. The result revealed that majority of the terrain of the Wilberforce Island had been highly degraded and urbanized without recourse to the Master plan.

The current settlement growth in Yenagoa has become a concern to urban environmental managers and Town Planners. Many researchers have examined effects of settlement growth pattern and on the environment employing various methodologies, too. Specifically, [5] examined the wetland changes that have occurred over the years in Yenagoa metropolis and their impact of rapid urbanization on environmental quality. The authors chose 5 zones known for high population concentration for the study with primary and secondary data analysed. The result showed serious abuses and contraventions on the environment which resulted in poor environmental quality. The limitation of this study was that though environmental quality is an aspect of urbanization, the authors did not dwell on management of urban growth. In yet another study, [6] carried out a study on effect of urbanization changes on land use in Yenagoa Metropolis, Bayelsa State (1986 2013) for investigation Landsat imageries of 1986, 2009 and 2013 were used. The result showed that built-up areas would continue to have serious impact on all other land use type. The limitation is that the study focused only on the effect of urbanization on some land use from $1986-2013$.

\section{STUDY AREA}

The city of Yenagoa grew as a linear settlement comprising of many villages stretching along the old Mbiama/Yenagoa primary distributor road, covering Four Local Government Areas; Kolokuma/Opokuma, Ogbia, Yenagoa and Southern Ijaw [16]. Yenagoa area lies along latitude between $4^{\circ} 48^{\prime} 00^{\prime \prime}$ North and $5^{\circ} 24^{\prime} 10^{\prime \prime}$ East; and longitudes between $6^{\circ} 12^{\prime} 00^{\prime \prime}$ East and 6³9'30" East [16]. It is bounded by Rivers State on the North and East, Delta State on the Northwest and West, Ogbia LGA on the Southeast and Southern Ijaw LGA on the Southwest [16]. With the creation of Yenagoa as the capital of Bayelsa State in 1996, population increase was rapid with about 30,000 persons moving into Bayelsa State and mostly Yenagoa Metropolis between 1996 and 2000 alone [16]. The city of Yenagoa was not planned for such massive in-flow of migrants, thus, it is important to monitor settlement growth and population changes because the growth of the settlement in turn affects the environment. Concisely, [2] was of the opinion that urban areas consumed quantities of energy (electricity \& gas), food (often transported on long distance), material (building and technological good), land (for building and recreation) and water. These urban areas generate large amount of wastes (atmospheric, chemical, water borne, solid and organic) into the environment. Management of these wastes is a concern in urban environment. Yenagoa as a new urban centre has been experiencing some of these problems. Remote sensing technique was used to achieve the aim of this work. Ground truth survey data (coordinates of identifiable points of the study area) from the Landsat imageries was used to calibrate remotely sensed data during geo-referencing.

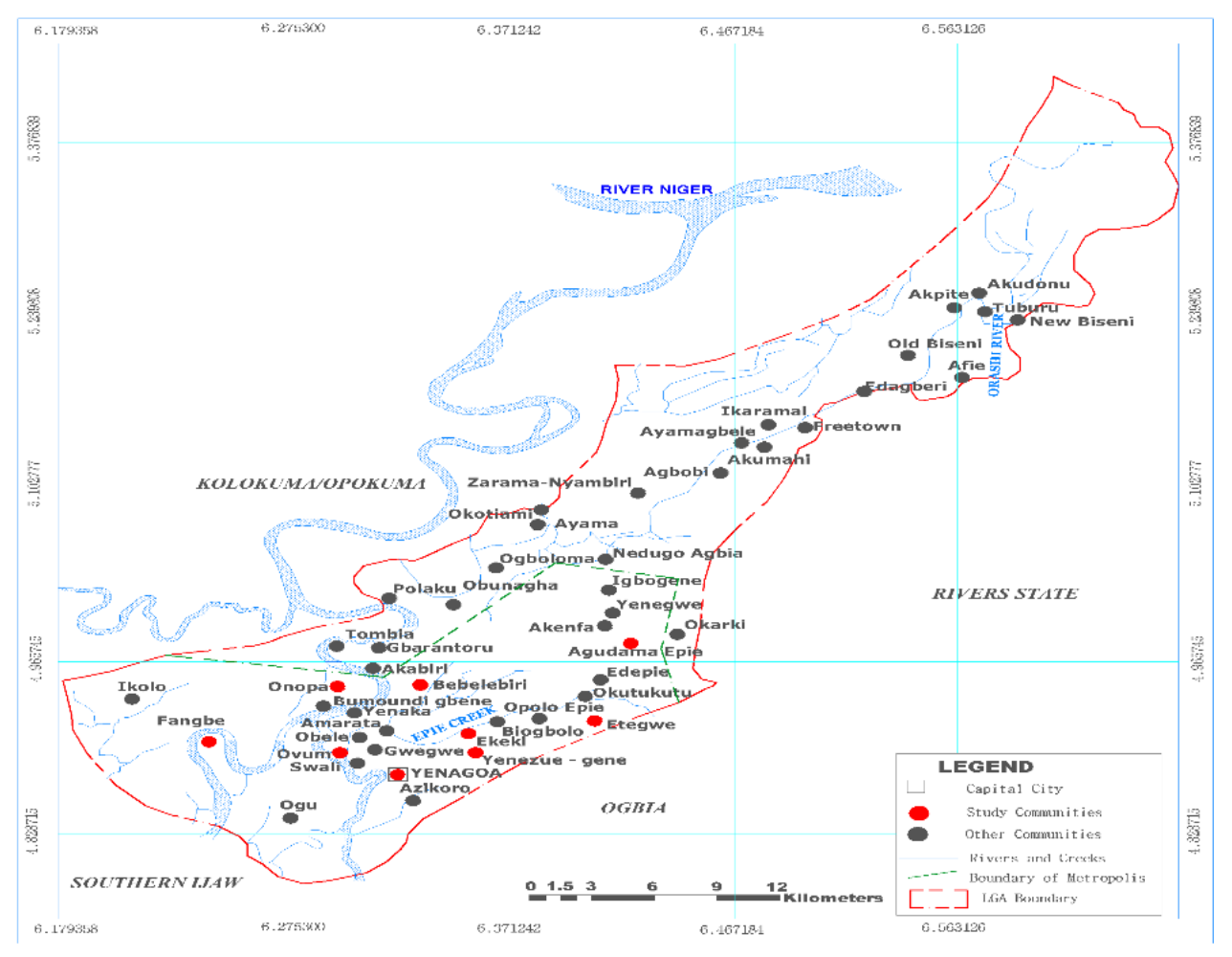

Fig. 1. Map of Yenagoa City showing communities and selected communities in the study area. Source: Author's Research 2020. 


\section{MATERIALS AND METHODS}

LULC features were clearly identified in the training site of the Envi5.0 GIS software environment, image clipping was performed and LULC was determined for each class with classified map for each epoch produced. This was analyzed using tables and statistical model describing epochal growth.

Data sets acquired were from Landsat satellite images of Bayelsa State for the years 1988, 1996, 2004, 2012 and 2020 with spatial resolution of $30 \mathrm{~m} \mathrm{x} 30 \mathrm{~m}$ Landsat. These satellite imageries were chosen because of its high resolution content, availability as at the time of this research and its capacity to provide the expected results of the research within specified epoch of interest. The instruments and equipment used for ground truth survey were Garmin 78CSx GPS receiver; field book, Casiofx 991 scientific calculator. Software/hardware used includes Hp Laptop computer with processor Intel® Core (TM2) Duo CPU P9700, 4.00GB RAM, and 64-bits operating system. ENVI 5.0, ESRI's Arc-GIS 10.3 (Arbi and Florjan, 2014) - vectorbased GIS software. The choice of Arc-GIS 10.3 was based on the ability to support vector analysis. ENVI 5.0 GIS software was be used to perform supervised image classifications. The Satellite images were geo-referenced in WGS-84 datum, UTM, ZONE, 32N. Satellite image was processed prior to image classification. The study area was clipped using shape file defining the extent of the study.

The classification was performed on the composite image in ENVI 5.0. According to [12] level 1 classification scheme was adopted to extract land use land cover categories. During image classification, land use/ land cover identified are built-up areas, water bodies and vegetation. Five epochs of the images (1988, 1996, 2004, 2012 and 2020) used in the extraction of built-up, water bodies and vegetation areas are shown in the figures $3.2,3.3,3.4,3.5$, and 3.6. The aerial imageries showed visible changes of Land Use Land Cover (LULC) with time for each epoch.

\section{A. Determination of Area and Percentage of LULC per Epoch}

\section{Area of LULC per Epoch}

The areas (hectares) of LULC for each epoch were determined after image clipping. Image clipping is an operation in the Envi 5.0 GIS software environment that identified the extent of LULC occupied by features of interest in the satellite imagery. The software automatically identifies and computes the area occupied by each features based on the classes of image classification.

2. Percentage of LULC per epoch

This was determined using the formular:

$$
\% \text { Area of LULC per epoch }=\frac{Y e}{Y A} \times \frac{100}{1}
$$

where $Y A=$ Area (ha) of land under study and $Y e=$ Total area (ha) of LULC per epoch.

\section{RESUlTS}

Below, are details for spatio-temporal changes and trend prediction over time for the study area.

\section{A. Spatio-Temporal Changes over Time}

Tables 1 and 2 below showed the extent of changes of the spatio-temporal characteristics and percentage area for LULC per epoch for water body, vegetation and built-up areas as considered in this study. It revealed water bodies either increased or decreased per epoch depending on seasonality of sampling or flooding patter as could be seen in 2012 when and where there was a nationwide flooding incidence in Nigeria.

In addition, it was also observed that vegetation gradually decreased from 1988 to 2020 as evidenced in Tables 1 and 2 respectively. More than $5 \%$ gradual decrease per epoch was consecutively noticed from 1988 to 2020 (Table 2).

Inter-epoch changes as documented in Table 3 further clearly showed the exact aerial changes within the geographical area over the time spans studied. Thus, results in Tables 2 and 3 clearly showed that while vegetation gradually decreased time from 1988 to 2020, built-up areas on the other hand gradually increased within the same time frames.

\begin{tabular}{cccccc}
\multicolumn{6}{c}{ TABLE 1: SPATIO -TEMPORAL CHANGES IN LULC AREA (HA) } \\
$\begin{array}{cccccc}\text { LULC } \\
\text { Features }\end{array}$ & 1988 (ha) & 1996 (ha) & 2004 (ha) & 2012 (ha) & 2020 (ha) \\
\hline $\begin{array}{c}\text { Water } \\
\text { Body }\end{array}$ & 880.74 & 709.20 & 712.98 & 1088.35 & 867.10 \\
Vegetation & $18,754.83$ & $17,708.31$ & $15,647.67$ & $12,022.73$ & $9,570.18$ \\
Built-up & $1,279.81$ & $2,497.87$ & $4,554.73$ & $7,804.30$ & $10,477.50$ \\
$\quad \begin{array}{c}\text { Total } \\
\text { Area(ha) }\end{array}$ & $20,915.38$ & $20,915.38$ & $20,915.38$ & $20,915.38$ & $20,915.38$ \\
\hline
\end{tabular}

It was found that by 2020 , built-up areas have taken up over $50 \%$ of the entire studied area's land mass. This showed that if this trend continues, that built-up areas would take over the entire land mass, thus taking up wetlands that are supposed to act as water reservoir, land for agrarian purposes and a host of others.

TABLE 2: PERCENTAGE AREA (HA) OF LULC PER EPOCH

\begin{tabular}{cccccc} 
LULC & $1988 \%$ & $1996 \%$ & $2004 \%$ & $2012 \%$ & $2020 \%$ \\
Features & & & & & \\
Water Body & 4.21 & 3.39 & 3.41 & 5.20 & 4.15 \\
Vegetation & 89.67 & 84.67 & 74.81 & 57.49 & 45.76 \\
Built-up & 6.12 & 11.94 & 21.78 & 37.31 & 50.09 \\
Total \% & 100 & 100 & 100 & 100 & 100 \\
Area(ha) & & & & & \\
\hline
\end{tabular}

The consistent increment in built-up area as opposed to water bodies and vegetation is an indication of settlement growth. Fig. 1 to 4 showed classified maps of the study area from 1988 to 2020 , respectively.

Fig. 1-4 revealed the extent of settlement growth in the urban area. In Table 2, the area of land covered by water body was relatively stable between each epoch with little changes, this reflected in the percentage covered in the study area as shown in Table 3, unlike the area used for vegetation, which witnesses tremendous negative changes, as several hectares of land use for vegetation were lost between each epoch. 
TABLE 3: SPATIAL CHANGE DETECTION IN AREA (HA) OF LULC PER

\begin{tabular}{|c|c|c|c|c|}
\hline \multicolumn{5}{|c|}{ EPOCHS } \\
\hline $\begin{array}{c}\text { LULC } \\
\text { Features }\end{array}$ & $1988-1996$ & $1996-2004$ & 2004-2012 & $2012-2020$ \\
\hline Water Body & -171.54 & +3.78 & +375.37 & -221.25 \\
\hline Vegetation & $-1,046.52$ & $-2,060.64$ & $-3,624.94$ & -2.451 .95 \\
\hline Built-up & $1,218.06$ & $2,056.86$ & $3,249.57$ & $2,673.20$ \\
\hline
\end{tabular}

However, there was a high increase in built-up from the second epoch of year 1996 till the fifth epoch of year 2020. Whereas vegetation witnessed continuous loss of land in hectares, as shown in Table 3, there was a total loss of 1,046.52 hectares between epochs of 1988-1996, 2,060.64 hectares between 1996-2004, 3,624.94 hectares between 2004-2012 and 2673.20 between 2004-2020 respectively for vegetation which may be as a result of increased urban expansion, thereby putting pressure on land used for vegetation in the study area. On the other hand, built-up areas gained several hectares of land continuously between the five epochs covering a period of 32years. Table 3.3 further indicated that built-up gained a total of $1,218.06$ hectares of land between epochs of 1988-1996, 2,056.86 hectares between 1996-2004, 3,249.57 hectares between 2004-2012 and 2,673.20 hectares between 2012-2020 respectively, this may also indicate possible continuous urban growth in parts of the study area.

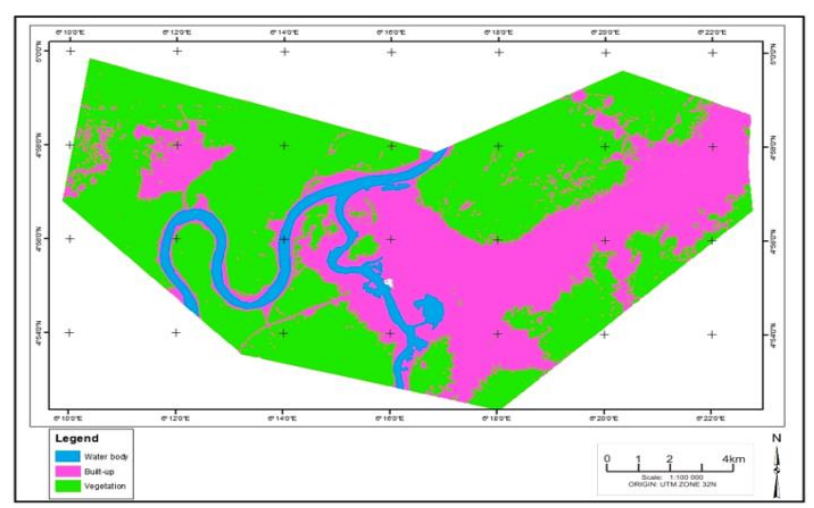

Fig. 1. LULC Classified Map for year 1988 Source: Author's Field Results 2020.

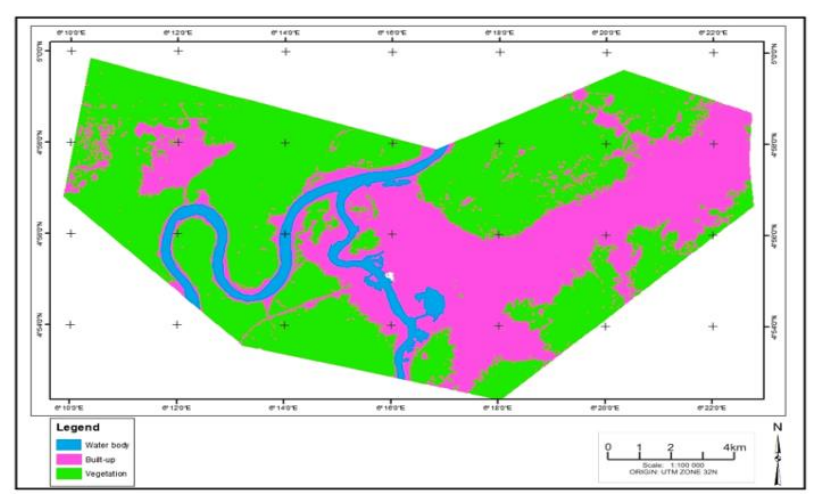

Fig. 2. LULC Classified Map for year 1996 Source: Author's Field Results 2020.

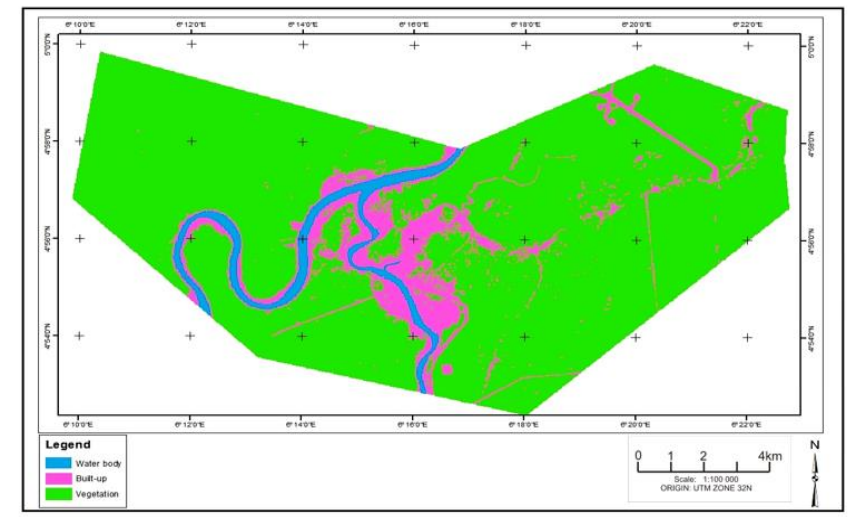

Fig. 3. LULC Classified Map for year 2004 Source: Author's Field Results 2020.

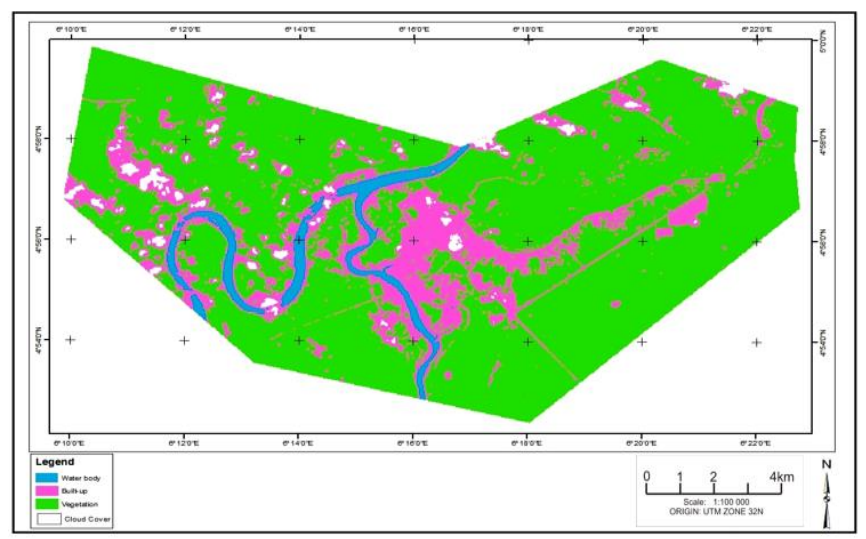

Fig. 4. LULC Classified Map for year 2012 Source: Author's Field Results 2020.

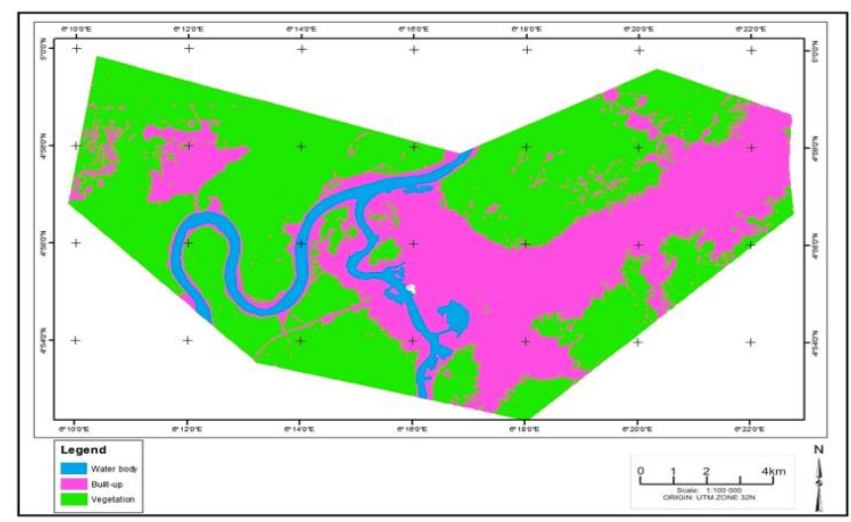

Fig. 5 LULC Classified Map for year 2020 Source: Author's Field Results 2020.

\section{B. Built-Up Area Trend Prediction}

Fig. 6 showed a linear graphical representation of the observed data, hence; linear regression model for trend prediction in time series adopted to predict the trends in built-up for period of 30years. This predictive model minimizes the difference between the observed data points and data points predicted by the regression equation.

The linear regression predictive model,

$$
Y t=a+b x
$$

was adopted for predicting the trends in built-up area over time. The model is a least square method of trend estimation in time series commonly used for calculating a regression equation. The method minimizes the difference between the observed data points and data points predicted by the 
regression equation. The trend equation $\mathrm{Yt}=\mathrm{a}+\mathrm{b} x$ is the arithmetic straight line representing the series in time $t[8,7$, 12]. Results of prediction of trends in built-up for the 30 years period is as shown below.

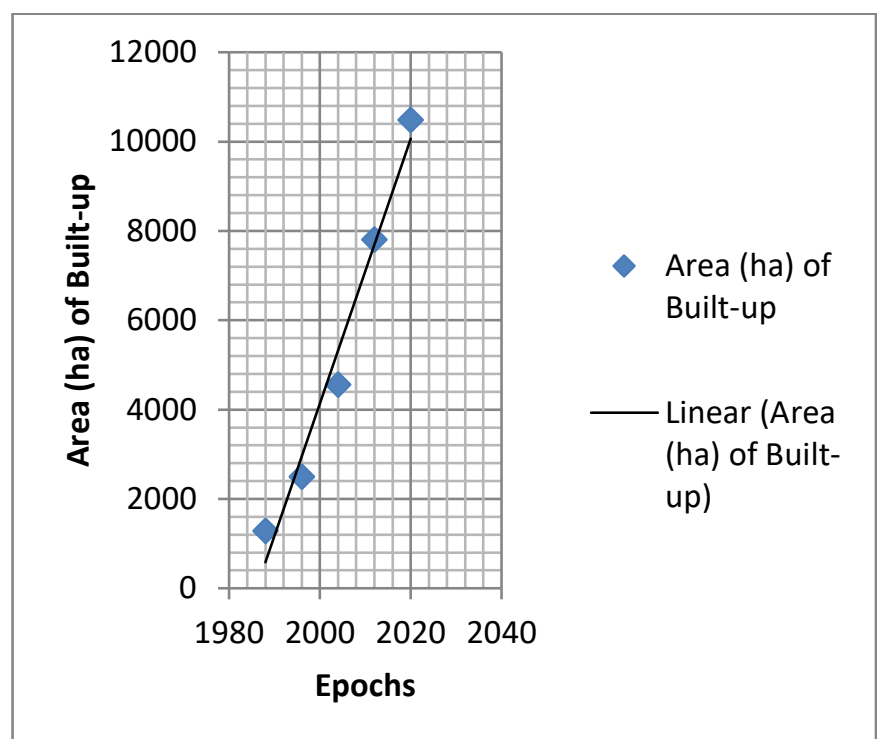

Fig. 6. Graphical Representation of Observed Data (Built-up) over Five Epochs.

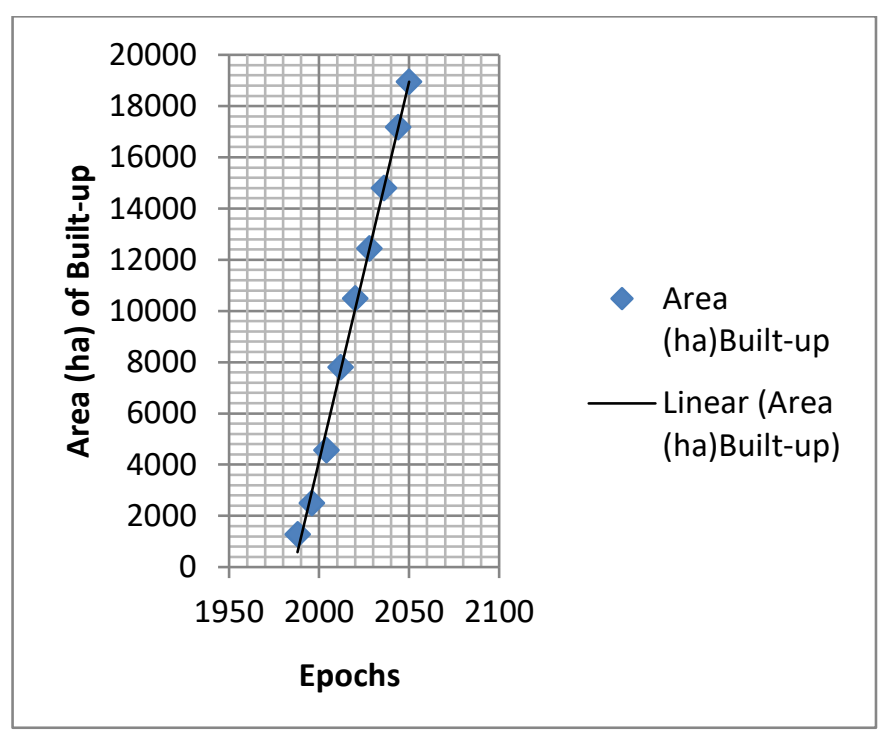

Fig. 7. Predicted Area (ha) of Built-up for period of 30years.

Fig. 6 and 7 showed the graphical representations of the area of land in hectares covered by water bodies, used for vegetation as well as built-up for five epochs in the study area as observed and computed after supervised image classifications. The graph (Fig. 6 showed that built-up areas were on the increase over the years with a linear upward area clearly shown. The persistence increases in hectares of land used for built-up prompted the prediction of trends in built-up for a period of thirty years (year 2020-2050) since this thesis is on settlement growth and its impact on the urban environment.

A linear area of built-up observed in this study prompted the use of the least square linear regression model for the prediction of trends in built-up over time. Furthermore, Fig. 7 indicated that built-up areas will continue to gain huge hectares of land and may take over land kept for vegetation and other features in the study area if it is not monitored and controlled by relevant authorities. The results of the prediction which showed linear areas in built-up between epochs revealed that a total area of 18,951.18 hectares of land will be used for built-up in the next 30years if it is not curtailed. This finding is consistent with that of [5] who in their study of wetland cover changes within Yenagoa metropolis established that $64.66 \%$ of the wetlands in the Yenagoa Metropolis have been lost between 1987 and 2015 with land area covered by wetlands consistently on the decrease with an annual change rate of $>-3.0 \%$ while the built - up area have been on the increase.

\section{CONCLUSION}

This study has revealed from Landsat imagery as classified in the maps of LULC from the Five different epochs that there were substantial spatio-temporal changes that have occurred in the study area. Results from Landsat imagery of 1988 showed water body accounted for $4.21 \%$, vegetation was $89.67 \%$ and built-up area was $6.12 \%$, respectively. In 1996 progressive changes occurred as Water body and vegetation reduced to $3.39 \%$ and $84.67 \%$ while built-up area increased substantially to $11.94 \%$. However, in 2004, Water body showed a little increase as against 1996 result reflecting $3.41 \%$ while vegetation further reduced to $74.81 \%$ and built-up area increased to $21.78 \%$. Results as recorded in 2012 revealed that Water body increased to $5.20 \%$, vegetation reduced to $57.31 \%$ and built-up area also increased to $31.31 \%$ while in 2020 Water body showed a decline to $4.15 \%$ while vegetation further decreased to $45.76 \%$ and built-up area increased to $50.09 \%$. The reason for increase in Water body in 2012 was as a result of the 2012 flooding that occurred across Nigeria then.

Urban growth and environmental changes have become an important public discuss to policy makers and environmentalist urban planners. This study has provided the impetus for further research in urban dynamics and management in terms of urban growth and development which has contributed to the body of knowledge of urban settlement growth and its impacts on the urban environment in developing economies especially in the Niger Delta region of Nigeria. This study is an assessment of settlement growth in Yenagoa and its impacts on the urban environment. This study has assessed urban changes that have occurred in Yenagoa City between 1988 to 2020 utilizing data from RS and GISR. Consequently, there is need to improve on urban environmental condition of the study area by suggesting urban planning and management measures that are sustainable to the settlement growth and environmental development of the study area. This will contribute to the advancement of the body of knowledge in urban settlement growth and urban environment and provide opportunities for further study of the subject matter. 


\section{REFERENCES}

[1] O. Agboola. Urbanization, physical development and Urban development in West Africa. A Paper presented at The Agenda Setting workshop of commonwealth Association of planners (CAP) 2006. World Planners Congress held between $14^{\text {th }}$ and $15^{\text {th }}$ November, 2005 at The Millenium Hotel, Sokode Crescent, Wuse, Zone 5, Abuja, Nigeria. November, 2005.

[2] D. Alemu (2016). The Boom in Infrastructural Development in Bayelsa state. The Nigeria voice Sept. 23, 2016.

[3] Anonymous (2020) Green Belt (United Kingdom) Available on www.bl.uk. 2020

[4] P. A. Bariweni and C. E. Andrew. LandUse/Land Cover Changes and Causes of Deforestation in the Wilberforce Island Bayelsa state, Nigeria. 2017.

[5] P. A. Bariweni and O. Amukali. Wetland Cover Changes in Yenagoa Metropolis, Niger Delta, Nigeria. Journal of Post Graduate School of University of Port Harcourt. 2: 1 - 7. 2017.

[6] O. Eludoyin, A. A. Obafemi and T. Hardy. Effect of Urbanization Changes on Landuse in Yenagoa Metropolis, Balyesa State, Nigeria (1986 - 2013). International Journal of Development and Sustainability, 6(8), 728 -745. 2017.

[7] P. I. Eze and J. Oriah. Geopatial Analysis of Encroachmentin Parts of Rivers State, Nigeria. International Journal of scientific research and publication. 8(9): 112 -120. September, 2018.

[8] S. P. Gupta. Statistical Methods. 42nd Edition, 2012. Sultan Chand and Sons Publishing, 23 Daryagani, New Delhi - 110p. 1969.

[9] A. A. Jamal. Managing Urban Growth in the City Amman, Jordan. Cities, 50, 93-99. 2015.

[10] A. M. Jinadu. Risk Sensitive Planning for Disaster Risk Reduction and Resilient Cities in Nigeria. In Ed. Disasters Risk Management in Nigeria Rural and Urban Setting. 34 - 42. 2015.

[11] I. Mahmoud. Analyses of Settlement Expansion and Urban Growth Modeling Using Geo-Information for Assessing Potential Impacts of Urbanization on Climate in Abuja City, Nigeria. 149p. 2016.

[12] F. N. Ogam. Foundations of Statistics and Probability Department of Mathematics and Statistics, RSU, Port Harcourt. 121p. 2000.

[13] UN Habitat. Development Context and the Millennium, Agenda the Challenge of Slums, Global Report On Human Settlement 2003. Nairobi, Kenya: UN Habitat. 2010.

[14] UIA. Unplanned Urban Development. The Encyclopaedia of World Problems and Human Potentials. 2018.

[15] K. Vermieren, V. A. Rompaey, M. Loopmans, E. Serwajja and P. Mukwaya. Urban growth of Kampala, Uganda: pattern analysis and scenario development. Landscape and urban planning. 2012.

[16] Yenagoa Master Plan. Yenagoa Master Plan. Government House, Yenagoa, Bayelsa State, Nigeria. 2004.

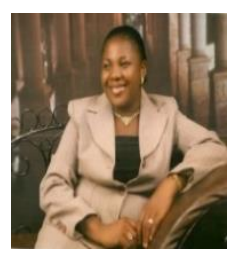

Tpl. Imaitor-Uku, Edith Ebinemi was born on $10^{\text {th }}$ may, 1972 in Nigeria. She holds a B. Tech. in Urban and Regional Planning, PGD in Education from Usman Dan Fodio University in 2010, M. Phil. In Environmental Management in 2019 and $\mathrm{PhD}$ in Environmental management and Pollution Control. She is presently a Chief Lecturer with Isaac Jasper Boro College of Education, Sagbama, Bayelsa State, Nigeria. She was Head of Unit of Urban and Regional Planning from 2003 to 2004 in Bayelsa State College of Arts and Sciences, Yenagoa, Bayelsa sate and later Head of Department of Geography from 2013 to 2015 in Isaac Jasper Boro College of Education, Sagbama, Bayelsa State, Nigeria. She is a member of Professional bodies like Nigerian Institute of Town Planners, Town planners Registration Council, Nigerian Environmental Society and Teachers Registration Council all in Nigeria.

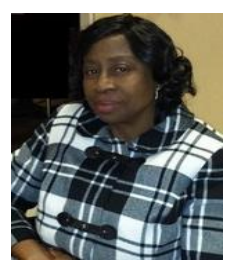

Prof. Opuenobo Binya Owei holds a Bachelor of Science Degree in Geography, a Master of Philosophy in Town Planning and PhD in Geography respectively. She is a Lecturer and Researcher who teaches undergraduate and graduate level courses. She also carries out consultancy services in Physical Planning unit. Currently she's serving in administration as Deputy Vice Chancellor (Academics) from June 20, 2019 till date in Rivers State University of Science and Technology.

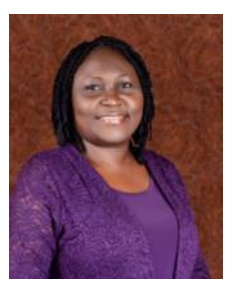

Dr. Ayotamuno Augusta is a Research fellow I at the Rivers State University of science and technology, Nkpolu, Port Harcourt, Rivers state, Nigeria where she has been since July 2012 till date. She holds a B-Tech in Architecture and M.Phil and Ph.D in Environmental management. Her areas of research interests are Climate studies, Built Environment and Sustainable Environmental Management.

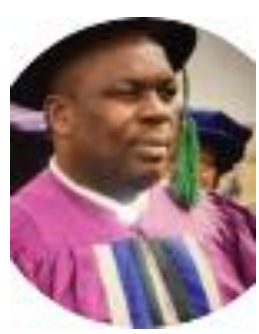

Dr Lawrence Hart is the current Head of Department of Surveying and Geomatics in Rivers State University of Science and Technology, Nkpolu, Port Harcourt, Rivers State, Nigeria. He holds a B-Tech from Rivers State University of Science and Technology along with M.Sc and Ph.D in Geodesy and Geoinformatics from University of Nigeria, Nsukka, Enugu State, Nigeria. His research interests are on Geomatics, environmental Engineering/Geodesy, Earth Mapping and Observations as well as Spatial and Numerical Analyses. 